\title{
Introduction
}

\section{Socialist interpretations of legal history}

\author{
Ville Erkkilä
}

This study of legal historians and legal histories written in Eastern European countries during the socialist era after the Second World War concentrates on a phenomenon of the recent past. Yet it speaks to the contemporary audience, who witnesses the challenging of the European ideal of the rule of law almost on a daily basis. Our book focuses on the way in which legal historians and legal scientists used the past to legitimise, challenge, and explain socialist legal orders that were backed by dictatorial governments.

The individual chapters of this volume concentrate on the regimes that are situated between the Russian (and later Soviet) legal culture and the area covered by the German Civil Code. Hence, the geographical focus of the book is on East Germany, Russia, the Baltic countries, Poland, and Hungary, but our approach is transnational. Instead of concentrating on the differences and distinct features of each national legal culture, we focus on the interaction and intertwinement of the then hegemonic socialist ideology and the ideas of law and justice as they appeared in the writings of legal historians and historically oriented legal scientists of socialist legal orders. Such an angle enables us to concentrate on the dynamics between politics and law as well as on identities and legal history.

Our aim is to study critically the presentations of legal history written under political guidance and to illuminate the ideological, academic, and biographical context of those presentations. Rather than reducing academic presentations on the history of law to mechanical extensions of the political order, the book perceives legal historiography as a form of the ever-ongoing dialogue between the political constitution of a society and the ideas of the rule of law and justice. Socialist legal histories were, nevertheless, attempts to reinterpret and give new meaning to the legal tradition after an abrupt change in the political and social context of law. Studying the temporal interpretations and representations of law of socialist countries enables us to provide a perspective on the more general problematic of law's embeddedness within societies.

It is clear that socialist interpretations of legal history were not written in an environment that followed the standards of the rule of law as described by present European convents and agreements. Due to that deviation, they also differentiated from their contemporary counterparts in the 'West'. The 'Eastern' and the 'Western' views diverged in their understanding of the limits of the 


\section{Ville Erkkilä}

executive power of the state and on the role of the legal order as an independent institute, but they also comprised two different regimes in using the past for redefining the relation between society and law.

After the Second World War in Western continental Europe, legal history was mobilised in the search for an untainted core of jurisprudence. Legal scholars attempted to locate the heart of legal principles that would not fall under totalitarian pursuits and could became a legal cornerstone for the slowly emerging coalition of the European nations. Legal historiography was dominated by the idea of the separate temporalities of law and general history (Koselleck, 1987; Wieacker, 1967). Jurisprudence was depicted as a system that could reinvent itself with the means of history, as a historically matured discourse which would enable a self-standing, self-regulating, and self-remedial matrix for mediating in disputes between the state and society (Liebrecht, 2018; Erkkilä, 2019).

The socialist regimes of East Central Europe perceived their societies according to a different concept of time. Marxism had revealed the underlying prior force of historical development, exposing the corrupted structures of thinking of the bourgeoisie, concurrently excluding other ways of conceptualising social activity. The establishment of the Soviet Union marked the beginning of a new era in which revolutionary ideas were put into practice. There was a singular, universal narrative of the historical development for society as a whole (Kolár, 2016, pp. 7-10; Schröder, 2016, pp. 64-65). The governments of the socialist bloc tried to control the idea of the separate temporality of socialist societies by 'rebooting' the revolution on a regular basis, sharpening the virtues of the true dogma and eliminating false interpretations of the revolution from the public sphere (Eckert, 1993; Poláčková and van Duin, 2019). A priority was also educating the people into dialectical materialist historical consciousness, in which the ruling communist parties invested a $\operatorname{lot}^{1}$ (Connelly, 2000, pp. 208-225).

In the West, legal scientists were not impressed by the socialist concept of legal history. Notwithstanding its constant reference to the historicity of social structures, it seemed that socialist jurisprudence was not taking 'the past' seriously, which became especially apparent in the sidelining and neglecting of the academic disciplines of historical studies, legal history included (Stolleis, 2009, pp. 16-18; Schmidt-Hartmann, 1988). After the fall of the Berlin Wall, there was little use for the Eastern European concept of history in European academia (Lässig, 2007; Varga, 2016, p. 647). Indeed, the legal historiography of the socialist bloc took place within a system where law as whole was an instrument of the ruling elite in its task of guarding and reforming society. Legal nihilism that some of the foundational theories of socialist law manifested reduced the space of jurisprudential reflection to a minimum.

Nevertheless, not many legal cultures in world history can be situated in a context of Rechtsstaat, and yet studying different perceptions and uses of the past in constructing legal orders is important for the contemporary idea of the rule of law (Reimann, Zimmermann and Glenn, 2019, p. 438). Our contemporary idea is subject to constant reinterpretation, discussion, and flux. The legal orders of socialist East Central Europe were subordinated to politics, but the ruling parties 
had to express and portray themselves as bound to a legal procedure and to legality (cf. Skinner, 2019; Fraser, 2019, pp. 33-38). In order to understand socialist legality in a way that is relevant for contemporary discussion, we need to make an attempt to understand its own logic, its perception of law's embeddedness in society, and its use of the past.

This volume scrutinizes the place of legal historical presentations between the coercive state and the tradition of legal scholarly independence. It analyses the ways in which historical knowledge was applied in commenting on socialist law; rather than depicting socialist interpretations of legal history as a monolithic entity, it highlights the contradictions within the discourse, continuities with previous legal cultures, and different adaptations of the hegemonic dogma of Marxist-Leninism. With this approach, the book addresses the question of the relations between state pressure, personal and scholarly views, and MarxistLeninism in (re)presentations of history. What was the impact of philosophical imperatives and the idea of a singular past on legal historiography? What kind of an effect did politically motivated structural changes in academia have on the production of legal historical knowledge? How were scholars able to find a space for the dissident use of the past within socialist jurisprudence?

In this introductory chapter, I will first give a brief overview of the political, ideological, and institutional context of socialist interpretations of legal history. This consists of discussing the concept of Sovietisation and outlining the effect that political socialism had on the legal orders, higher education, and legal cultures of the countries of East Central Europe. This is followed by a conceptualisation of the space of legal historical presentations within state socialism. My contribution ends with short descriptions of the individual chapters of this volume and the way they are thematised.

\section{Sovietisation, socialism, and law}

Here, Sovietisation means the tactics with which the Soviet Union attempted to rule the areas it had conquered during the Second World War-all aimed at stabilising the Soviet hegemony in the regions of East Central Europe and Baltic Countries and disseminating the revolutionary ideas on the state, politics, and the rule of law initially introduced by the Bolsheviks. It is not my intention to devalue the factual influence the Soviet Union imposed on the societies of East Central Europe but rather to question the one-sided idea of Sovietisation. After Stalin's ruthless use of unreserved terror, there was no supreme plan or even consensus among the commissariat for the means and subsistent goals for Sovietisation (Naimark, 2017; Kramer, 2017).

For Estonia and Latvia, there was no escaping their fate as fresh states in the Soviet Union. Their population was perceived with suspicion and given a 'precautionary procedure' (meaning, e.g., mass transportations to Siberia), and their short-lived national political and legal systems were replaced with Soviet ones (Kirby, 1994). Whereas the Baltic states were treated in a very similar fashion to the regions in the Caucasus and the Far East, which the Soviet Union assimilated 


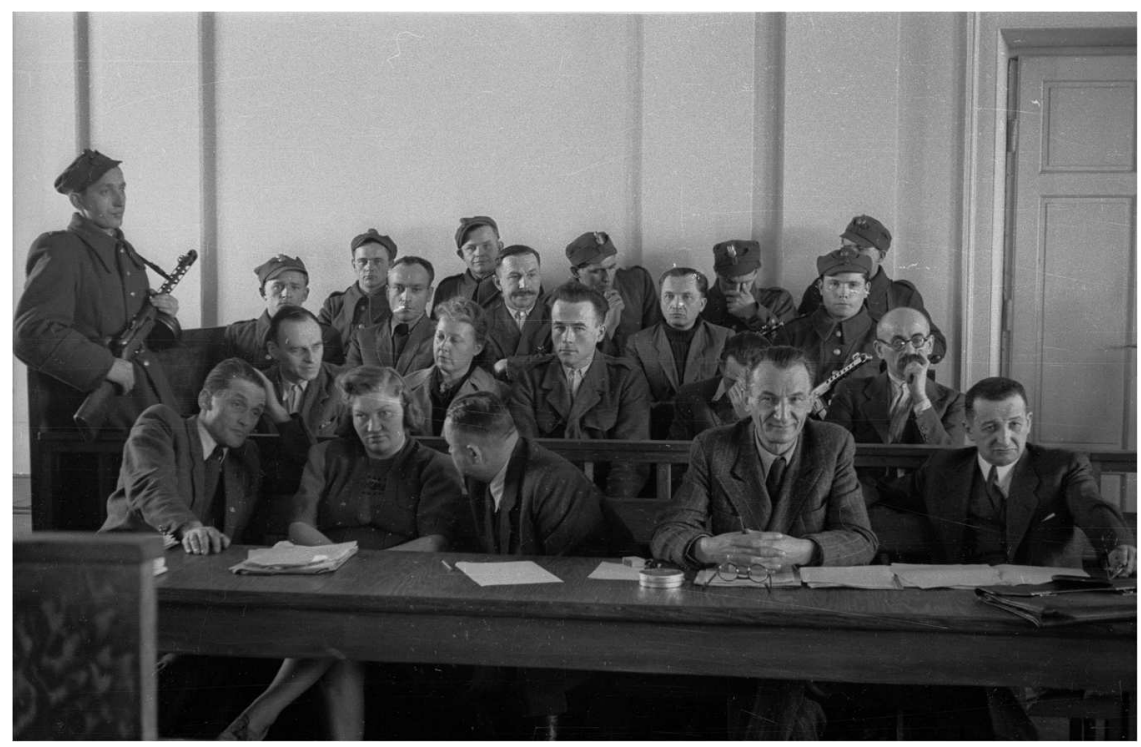

Figure 0.1 Polish war-hero, resistant fighter and spy for the Allied West Witold Pilecki at his show trial in Warsaw on March 3, 1948. Pilecki was executed two months later. At the picture Pilecki is sitting first on the left in the second row. In the first row are the solicitors.

during the interwar years, the protocol was not as lucid with regard to the countries in East Central Europe that fell under Soviet occupation from 1944 to 1945 (Naimark, 2017, pp. 63-65). Stalin himself, apparently lacking a preconceived and consistent blueprint for disseminating the communist revolution to East Germany, Czechoslovakia, Poland, and Hungary, announced the possibility of 'different paths' to communism (Naimark, 2017, pp. 65-70).

Such a stance seemed to emphasise the varying cultural and historical background of each region in their transformation process. Notwithstanding the comradely tenor in the 'soft' approach adopted by the Soviets and their cautious take on immediate implementation of major social reorganisations, such as sweeping collectivization, they did pay attention to the reorganisation of higher education and facilitated decisive attempts to convert the legal institutes of the regions they occupied to socialist institutions. Such an act of shaping the essence of domestic judicatures was carried out by replacing the judiciary with more 'classconscious' lay judges and putting on display trials for the 'enemies of the working class' (Haferkamp and Wudtke, 1997; Kaluza, 1999; Boros, Gyulavári and Fleck 1999, pp. 147-151).

The protests of the 1950s and 1960s-both in the visible form of demonstrations and strikes and in the indiscernible moves to resist socialist reforms-laid down the ground for the later national character of each satellite state within the socialist bloc (Kramer, 2017). In East Germany, the political elite 
crushed the 1953 uprising with the help of the Red Army and succeeded in building a remarkably stable socialist system (Ostermann, 2001). The East German model was characterised by a tight grip of the state apparatus where there was little room for serious dissidence. In 1956 Poland and Hungary revolted. The Hungarian uprising was quashed by ruthless military intervention, but the Polish domestic leaders were able to convince Moscow that the use of brute force was unnecessary and inner-state measures were sufficient to keep Poland a loyal member of the flock (Kramer, 2017, pp. 148-154). In Poland, the national identity continued to play a significant role throughout the latter half of the 20th century, whereas in Hungary the memory of 1956 stood between many individual worldviews and the official jargon of socialism.

The socialist bloc was genuinely recreated in 1968. Crushing the dissident spirit of the 'Prague Spring' solidified the Brezhnev doctrine as a rule in defining the relations between the East Central European countries and Soviet Union on the one hand and between the satellite states themselves on the other (Kramer, 2017, pp. 159-164). Around and after the Helsinki Accord of 1975, when human rights became a worldwide lingua franca for evaluating political systems and efforts, socialist countries vocally defended their version of the rule of law and sharply criticised the 'Western world's' hypocritical advocation of subjective rights (Mälksoo, 2018; Kopeček, 2012). That paradigmatic change engaged many Eastern European legal scholars, but the broadened discussion at the same time inevitably revealed the inherent contradiction between the ideological principles and their practical implementation in state socialism.

Thus, the four-decade era of the Soviet influence in East Central Europe was characterised by a varying regional emphasis and temporal changes in the measures selected, not to mention the actual reception of the Soviet import of socialism. As John Connelly puts it:

SED members may not have taken socialism seriously, but they and the East German population took the state very seriously [...] Czech comrades may not have taken the state very seriously but they did believe in their version of socialism [...] Poland's Party cadre took neither the state nor socialism very seriously. (Connelly, 2000, pp. 284-287)

Whereas Hungarian scholars were able to negotiate between their domestic tradition and Sovietisation, and the jurisprudential tradition of the Soviet Union was far from being a monolithic one, Baltic legal scholars had no choice but to take both the state and socialism very seriously.

All Soviet satellite states were, nevertheless, socialist countries, and their political and legal systems can be safely characterised as state socialist. According to Peter C. Caldwell, state socialism attempted to guarantee the proclaimed uberdemocratic and anti-fascist essence of socialist societies-especially in comparison to Western countries and Western science-by giving the 'state plan' the final say with regard to politics, economy, and law (Caldwell, 2003). Yet by doing so, state socialism had to provide the state with a special position above the law and 
suppress some of the basic civil rights of its citizens; sacrifice legal certainty and equality in order to safeguard the alleged and necessary cohesion of society; and, by announcing that its politics merely implemented the will of the people (i.e. the 'working class'), had to surveil and uproot disobedient and potentially harmful ideas from the public sphere. In order to cope with the dilemma, the MarxistLeninist dogma of the socialist bloc equated the will of the people with 'the state' and further concentrated the power of the state apparatus into the hands of a small elite, that is, the executive organs of the domestic communist parties (Schröder, 2016, pp. 61-62, 78).

The starting point for all socialist legal orders in 20th-century East Central Europe was the Soviet example - not their domestic and national traditions of socialism-and its concrete measures in reorganising the legal institutes as well as the political manifestations of Marxist-Leninism born out of and in the midst of that Bolshevik experiment (Markovits, 1968; Bender and Falk, 1999, pp. XIII-XIV). According to Lenin, the Soviet Union had taken the Marxist principles to a new, practical level with its concrete fighting, first visible in the October Revolution and further advanced in the actualisation of 'real socialism' (Zagladin, 1983, pp. 6-7).

The Marxist-Leninist dogma, which was a reinterpretation of the original Marxist thought, served as a wrapping in drafting, evaluating, and implementing law (Bender and Falk, 1999, pp. XI-XIII; Schröder, 2016, pp. 66-67). Intact in this dogma was the Marxist core of the foundational mission of the working class: dismantling the bourgeois society and its repressive structures via revolution and building a new socialist society, which would ultimately develop into communism. Such a process was to be achieved by cultivating the consciousness of the working class and fighting against the sabotage of the imperialistic enemies of the state and the socialist process (Zagladin, 1983, pp. 14-16).

The Marxist-Leninist dogma was translated to the national legal orders of the Soviet satellite states by the domestic communists approved by Moscow and the Soviet experts working in the countries in the socialist bloc (Connelly, 2000, pp. 68-69). The possible leeway for renewal, criticism, and new openings happened within this frame. Marxist-Leninist dogma-as steered and reinterpreted by the domestic communist parties-was the ius commune of the satellite states (Schröder, 2016, pp. 68-69). Furthermore, dissident voices were judged by their heresy with respect to the 'true meaning' of Marxist-Leninism, being judged as 'revisionism' or 'too formalistic.'

The national constitutions of the Soviet satellite states toed the line of the 1936 Constitution of the Soviet Union, which was assembled by Stalin's chief prosecutor, Andreii Vyshinski. The most prominent principles in the 1936 Constitution-and later in the Constitutions of the East Central Europe-were the democratisation of justice; the substitution of subjective rights with an assortment of social rights and civic duties of citizens; and, contrary to the Soviet Constitutions of 1918 and 1924, allotting the communist party an established position in coordinating and representing the will of the working class (Pomeranz, 2019, pp. 86-88). Although the state socialist governments later to 
a degree tried to distance their legal orders from Vyshinskian legality,' the abovementioned basic principles remained (Stolleis, 2009, pp. 25-27; see also Richardson-Little, Dietz and Mark, 2019).

In principle, judges, lawyers, and legal scholars did not have the authority to interpret and further develop the law but to implement it (Schröder, 2016; Gizbert-Studnicki, Pleszka and Wolenski, 2016). This led to a 'hyper-positivist' reading of civil codes, with which judicature intended to secure their own position but also to make their case in such a way that there would be as little room as possible for questioning their arguments on political bases. Rather than being Rechtsstaats, the legal orders of the East Central Europe were 'norm-regimes' (Normenstaats) (Stolleis, 2009, p. 38).

The Soviet Union to a degree watched over the legal development of its satellite states. Sometimes in concrete administrative problems, the Soviet communist party expressed its 'opinion' on the preferable solution via the common networks of the socialist bloc or through diplomatic connections. ${ }^{2}$ Especially important was to homogenise the legal concept of property, and socialist legal systems all, in one way or the other, adopted the idea of socialist property as defined by soviet legal theoristVenediktov (Raff and Taitslin, 2014). Nevertheless, soon after the end of the Second World War, in accordance with the 'different paths' doctrine, Stalin published his reinterpretation of MarxistLeninist dogma, where he rearranged the relations between 'base' and 'superstructure' (Stalin, 1951). This enabled the domestic leaders of the socialist bloc to maintain their national civil codes, and rather than focusing on repealing the existing legal orders, the communist party elite could concentrate on controlling the interpretations of private law, in which legal history played an important role.

\section{Higher education in socialism and national legal traditions}

Education had a central position in the state socialist ideology of East Central Europe. That was due to Marx's emphasis on cultivating the consciousness of the working class as a prior task for the communist party but also to the aim of Leninism to distinguish the party cadre from the old institutions in establishing a new social elite (Lenin, 1977, pp. 23, 375). In the reality of post-Second World War Eastern Europe, it meant dismantling the prestige of the old academic bastions; replacing the university staff with a new, loyal one; and erecting new facilities of higher education aside from the universities.

Seizing the monopoly on education was vital in view of raising a new social elite from working class youth, but another, and in practice at least important, objective was the training of a new class of judges. The 'democratisation' of justice necessitated the replacement of the old judiciary with 'people's judges' whose education was situated-or at least that was the plan-outside the legal faculties (see, e.g., Schröder, 2016, p. 73; Boros, Gyulavári, and Fleck, 1999, pp. 344-359). 
In general, state socialist governments determinedly diminished the societal significance of the traditional law faculties in favour of the natural sciences, new institutes of a technical character, or newly established academies for delicate disciplines like law or social studies (Stolleis, 2009, pp. 47-49, 121-122; Connelly, 2000, pp. 60-61, 67-70). The reforms for higher education were steered from offices and ministries of education under the leadership of the domestic communist parties and concentrated on recruiting students from working class backgrounds or people whose preliminary training consisted of courses in Marxist-Leninism. The aim of the educational means, such as regular revisions of the legal curricula, was to control the judiciary and legal scholarship in each of the satellite states (Haferkamp and Wudtke, 1997; Bena, 1999, pp. 377, 406).

In the Soviet Union, Bolsheviks had determinedly stripped the 'bourgeois traits' from universities. Already before the Second World War, social sciences had undergone a process of reorganisation in which the disciplines across the spectrum had been merged into a branch of "new historical science"3 (Fitzpatrick, 1979). In Soviet satellite states, the adaptation of the Stalinist view in the national cultures of higher education was, again, a more complex and dynamic thing. The universities within East Central Europe had all adhered to a Humboldtian ideal of free scholarship and could build on a prestigious past even though their individual national histories were very different. In addition, the universities had opted for different adaptation strategies in the face of the preSecond World War National Socialist onslaught and had a varying relation to the middle and working classes of their respective nations (Connelly, 2000, pp. 2-16). Thus, the Sovietisation of the higher education in the Eastern bloc-despite considerable effort to produce homogeneous institutions in their aims and ethos-produced diverse results.

The Soviets considered the German professoriate thoroughly corrupted by fascist ideas, and, in accordance with the Western occupation zones, conducted a sweeping 'denazification' within the universities during 1945-1946 and ousted approximately $80 \%$ of the professors on the bases of their involvement in fascist policies and their memberships in the organisations of the National Socialist German Workers' Party (NSDAP). What made Soviet denazification different from the Western equivalent was its thoroughness and rigour. Although some of the removed staff were later able to return to a teaching position, there was no general amnesty for those who had been denazified (Stolleis, 2009, pp. 45-46).

Denazification paved the way for reintroducing German universities as reproducers of Marxist-Leninism, and, indeed, German professors and students seldom openly challenged the party policies but rather internalised their mission as a loyal instrument within state socialism (Markovits, 2018, pp. 44-48). As a state, the German Democratic Republic (GDR) was an anomaly in the socialist bloc. It was a model region among the Soviet satellite states despite its culture, history, and legal tradition that had just recently been forged into a totalitarian society and turned against the Soviet Union. The memory of a common past and legal culture 
with the Western neighbour never ceased to exist, and relations with the Federal Republic of Germany (FRG) and 'Germanness' very much overshadowed legal historiography, despite serious efforts to the contrary (Joseph, 1995, p. 584).

The main tenet in pre-Second World War jurisprudence in Hungary-unlike, for example, in Czechoslovakia (Bröstl, 2016)—was the dominance of the legal sociological stance and the rejection of the strict legal positivism of the Vienna School. It might have been the Hungarian legal scholars, nevertheless, who were able to cultivate the narrow Vyshinskian dogma furthest and into scientifically considerable legal theories, but naturally not outside the Marxist-Leninist frame (Varga, 2016). The coercive politics of state socialism also restricted the academic institutions in Hungary, and the shadow of the crushing of the 1956 uprising constantly hovered over civil society, reminding scholars of the limits of academic freedom.

It is not perhaps a coincidence that the first socialist Civil law code of the Soviet satellite states was promulgated in Hungary in 1959. Vilmos Peschka and Imre Szabó were renowned legal theorists in the socialist bloc, and their legal philosophical follow-up on Soviet 'revolutionary legality' was a starting point for a substantial body of socialist legal scholarship (Schröder, 2016, p. 80). In the discipline of legal history, the works of Hungarian scholars gained wide attention, and probably the most famous of them was the Roman law scholar Elemér Pólay. Pólay contributed significantly to the contemporary study of the history of Roman law and enjoyed wide appreciation in the West. Paradoxically, while in the West the narrative of Roman law was used to back up the freedom of private property, Pólay used the same narrative to outline the scientific standards of legal historiography in compliance with the Marxist understanding of historical development.

In Poland, Sovietisation measures failed to dismantle the traditional prestige of university professors. Moreover, the Polish national version of state socialism maintained and cultivated a strong notion of national identity and an idea of the special, historical path of Polish society and its structures (Connelly, 2000, pp. 127, 142-161, 283-284; Danyel and Behrends, 2019, p. 9). Among the countries in the socialist bloc, Poland's jurisprudential culture was the most pluralistic. The state did, however, control academic freedom and during internationally or domestically tense periods, the state's grip was tighter, e.g., in the form of censorship, than normally (Danyel and Behrends, 2019, p. 154).

After the Polish thaw (the 1956 revolt and its nonviolent ending), it was possible in Poland to portray oneself as a non-Marxist legal scholar, a combination of words that would not have been possible, for example, in the GDR. Polish legal scientists were entitled to a creative use of Marxism, but they were also aware of and discussed Western legal theories from Kelsen to Hart (GizbertStudnicki, Pleszka and Wolenski, 2016, p. 567). Poland's national legal culture was characterised by the heritage of Leon Petrazycki, whose remarkably wide learnedness and oeuvre benefited the whole field of Polish legal sciences and formed a basis for further innovative theorising in the latter half of the 20th century (Cotterrell, 2015). 
Polish legal science was, however, careful not to cross the line and provoke the political sphere-a stance that might well represent Polish civil society in general during the 1960s and 1970s (Fijalkowski, 2016; Danyel and Behrends, 2019, pp. 150, 154). The authority to draft and further develop laws was the sole privilege of the state and the communist party. Lawyers or judges did not interpret the law in ways that would have resulted in precedents in further uses of the law. They studied the existing law and went no further. It was not possible, or at least not wise, to evaluate the existing law in the light of justice or fairness or any other criteria (Gizbert-Studnicki, Pleszka, and Wolenski, 2016, p. 581). But by means of legal history, it was nevertheless possible to indirectly challenge the existing legal order.

\section{Mapping a space for socialist interpretations of legal history}

The political frame of Sovietisation, the ideological language of socialism, and the concrete restrictions on the academic space of legal historians composed a framework for the legal historiography of the East Central European countries from the late 1940s to the final years of 1980s. In many cases, the academic careers of scholars depended on the level of loyalty they expressed towards the leadership of the communist party. Especially in the Baltic countries, the parallel state of the secret police watched over the teaching of academics, and its existence had to be taken into account in all scientific activity.

Concentrating on these boundaries, however, leaves scholars as mute reproducers of the hegemonic discourse and ignores their own identity and agency as citizens, scientists, and moral beings. In fact, the framework was not stagnant but historically situated. The context of Sovietisation in itself brought about constantly shifting circumstances within the fields of the domestic sciences. Both the state and legal historians had their opinions on the ways in which 'the past' could be mobilized in socialist societies on their historically determined journey to becoming communist.

Most of the legal historiography produced in the socialist bloc toed the official line and produced results that supported the self-justification of the socialist state. It presented socialist legality as a historically evolved model that, by adhering to the scientific principles of Marxist-Leninism, efficiently implemented the 'will of the people' in administration and legal institutes and as a system that was both equal for all and able to keep up with the pace of historical development. Consistently, by means of using the past, socialist legality was shown to be the ultimate answer to the perennial questions of justice, freedom, and democracy, while the Western idea of the rule of law appeared as its mere negation, 'imperialistic,' corrupted, and 'fascist' (Stolleis, 2009, pp. 27-31, 41; see, e.g., Tschernilowski, 1980, pp. 27-31).

Socialist legal historiography should not be perceived as a dysfunctional copy of the Western ideal, nor as a diluted application of the Bolshevik model of 'revolutionary legality' but as an autopoietic system that functioned according to 


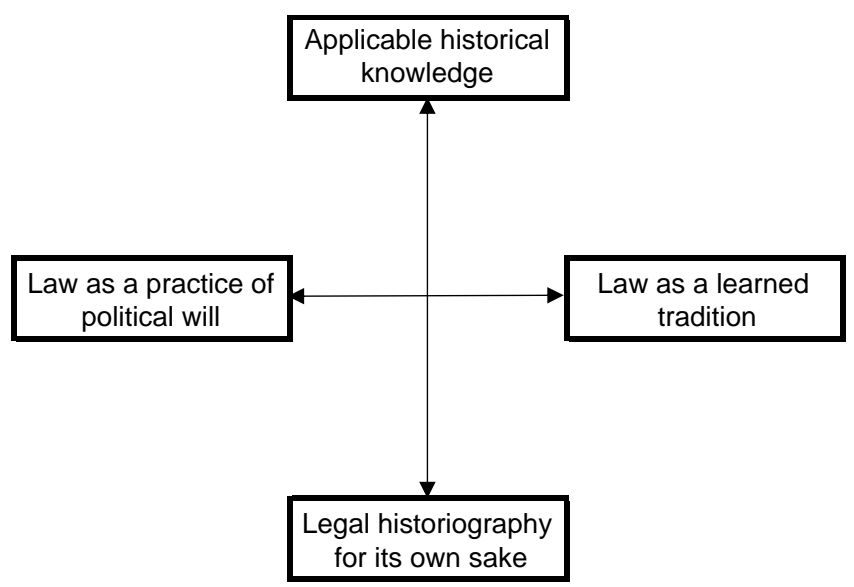

Figure 0.2

its own dynamics and rules, unavoidably connected to the past it shared with the 'Western' legal tradition (Luhmann, 1984). In what follows, my attempt is to describe the tension, on the one hand, between the state direction ("law as a practice of political will') and the autonomy of the legal historiographical discipline ('law as a learned tradition') and, on the other hand, between legal historical presentations whose primary aim is to comment on the phenomena of their contemporary society ('applicable historical knowledge') and histories that seek to exclude any direct relevance with their social-political context ('legal historiography for its own sake'). Associating these two axes in a scheme creates a model with which both the dynamic and historical nature of legal historiography can be analysed. ${ }^{4}$ The socialist interpretations of legal history can be mapped within this space and between those polarities.

The tension in the horizontal axis between the ideas of law as a 'practice of political will' and 'learned tradition' did not lie in questions whether antifascism/anti-imperialism was a righteous norm for common identity or whether Marxist-Leninist dogma was an accurate matrix in steering society. The majority of scholars did not question, or had no choice but to accept, these principles. Furthermore, legal historiography in socialist countries did not challenge the instrumental essence of law in executing the 'state plan' of the domestic communist parties. The Marxist-Leninist methodology, as it displayed itself in legal historiography, can be described in a nutshell as follows:

The economic structure of society is the base from which the superstructure arises. The superstructure consists, for example, of the state as well as the religion, law, and philosophy of the given society. The various elements that make up the superstructure significantly influence the processes that take place at the base. ${ }^{5}$ Also crucial is the way in which actual social events and developments are reflected in the minds of the participants and their political, legal, philosophical, 


\section{Ville Erkkilä}

and other views. Nevertheless, the state and law in the last instance are always determined by the economic conditions. Class antagonism creates the state and its legal system, and they can be conceptualized only in terms of class. Regardless of its multiple manifestations, the state is nothing more than the organised collective exercise of power of the propertied classes. Its law is an expression of the interests of the ruling class. These interests do not arise arbitrarily but are always dependent on the respective conditions of production, 'objectively' conditioned. With the help of law, the ruling class secures its control over the other classes and strata of societies (Tschernilowski, 1980, p. 26; also Sellnow, 1963).

The idea of 'law as a learned tradition' in implementing Marxist-Leninist dogma was not an ideal but a tacit $i d e a$ that consisted of many different particles. Central was the romantic notion of law as a concrete manifestation of legal thinking (Schröder, 1980; Klenner, 1957, pp. 82, 84). Legal history was a narrative of the relation between law and society. It valued the past expressions and representations of law (in other words, the European legal tradition) as examples of a particular, legally oriented thinking, and learning from them was useful for contemporary socialism (Joseph, 1995, p. 584). The study of these past expressions had to respect the characteristics that distinguished legal thinking in the first place; in other words, one had to have a legally trained and conscious mindset in writing legal historiography (see, e.g,. Csizmadia, 1968, pp. 104, 114; Schöneburg, 1987, pp. 309-310, 319-320).

The idea of 'law as a learned tradition' bore some resistance to Sovietisation and implementations of 'socialist legality.' Especially in the Baltics, it was a concept that embedded the preservation and cultivation of national identity. Both history and legal history were spheres where the characteristics of different ethnic groups could be given a voice (Kolár, 2016, pp. 143-147). It did not comprise, however, a coherent ideological alternative for socialist legal science, and legal historians who advocated the idea did not perceive themselves as belonging to a particular school of thought. Especially in retrospect, many scholars claimed that their only goal within the state socialist society had been defending science (Wissenschaft) and the institutions that represented it, but on closer inspection, what they really might have defended were the privileges of the professoriate or the social status of the academic (Connelly, 2000, p. 283).

Neither of the ideas existed in their absolute form. It was not possible to retreat exclusively into a world of pure legal methods and scientific standards in a socialist science community. At least if one wanted to make a career. And yet a legal historical study that would have analysed law from an overtly orthodox starting point in which law was politics per se was not useful in legal education or in real administrative challenges. Even for an 'advanced socialist nation,' training judges capable of ruling on the basis of, and according to, the 'socialist consciousness,' or building a legal order where some legal certainty prevailed, without taking into account the jurisprudential tradition, was impossible.

The same requirement for adhering to and expressing 'socialist consciousness' also applied to legal scholars. State socialist governments attempted to bind 
scientific thinking to their political aims and harness it in building a communist society. The political instrumentality of law as expressed in legal curricula and in the announcements of the party assemblies also demanded 'responsibility' from legal historians, and their representations had to advance the cause of international revolution (Stolleis, 2009, p. 34; Joseph, 1995, p. 557): ${ }^{6}$

While the bourgeois historian seeks to disguise his partisanship, the Marxist historian frankly takes the side of that class whose representative he is himself, openly advocating the positions of the working class, which is the only progressive social class. (Tschernilowski, 1980, p. 27) ${ }^{7}$

That sphere of 'socialist responsibility' was, nevertheless, not merely restrictive in nature. Many scholars genuinely believed in the anti-imperialism and anti-fascism of socialism, and even if they did not, especially the older generation of researchers had a vivid memory of the fascist totalitarianism of the 1930s and 1940s. To legal scholars in the latter half of the 20th century, it was equally clear that the idea of 'law as a learned tradition' had not been able to resist the National Socialist attack (Caldwell, 2003, pp. 71-73). Whether the West continued to be possessed by those traits was debatable, but the Eastern European media was quick to point out, for example, the faults in the West German denazification programme and the capitalist connections-real or alleged-in the scholarly culture of the Western world (Joseph, 1995).

Adhering to and expressing 'socialist consciousness' was a largely accepted state of affairs, although many privately grieved for the incomplete political execution of that ideal. Certainly, some legal historical studies had opportunistic intentions, and quite a few scholars adopted an indifferent attitude towards socialist ideology (Danyel and Behrends, 2019, pp. 207-230). Yet the 'emancipatory' ideal of socialism remained more than rhetoric to many scholars; thus, rearranging the relation between 'law as a practice of political will' and 'law as a learned tradition' was in some sense justified to them (Heuer, 1995).

In this space between the polarities, the communist governments regularly attempted to move the focus more towards the 'practice of political will.' They did this by rebooting legal curricula and by 'starting the revolution anew' on a regular basis in party assemblies (Markovits, 1968, pp. 14-15; Joseph, 1995; Danyel and Behrends, 2019, p. 214). In these events, the political guidelines and limitations for social sciences for the next few years were announced. Sometimes there was a public denouncement of legal scientists who had deviated from the implicit guidelines set by the party elite. Sometimes another scientist, stronger in his or her faith in the party, flayed the heretics and their indecent works in the pages of the few scientific journals (see, e.g., Otto 2008, pp. 375-382). Constant outcries about placing 'practice' over 'theory' in public statements were also expressions of the need of the communist parties to place legal science within the same revolutionary narrative than the rest of society (Haferkamp and Wudtke, 1997).

The vertical axis in the figure, between 'applicable historical knowledge' and 'legal historiography for its own sake,' stands for the tension between the 


\section{Ville Erkkilä}

polarising extremes in using the past. In the German legal science tradition-whose influence stretched far to the east and south beyond the actual borders of the German Empire-history had always had a special place. In the Central Eastern European legal systems that rested on a codification of law, arguments in interpreting and developing the law were derived from the classics of the legal tradition and preceding works on the national legal problematic. It was the task of jurisprudence to reinterpret its own tradition in order to come up with solutions in situations where the social need or new legislation was possibly in conflict with the letter of the law (Liebrecht, 2018). Thus, in East Central European societies in the early 20th century, legal historical knowledge, produced both in the past and in contemporary legal science, was highly relevant since it could be used to adjust the legal framework and to set the rules within which all other social activity took place.

In principle, admitting the historical nature of law and legal order as well as continuity in the legal sphere was a very difficult question for communist parties. On the one hand, the socialist revolution for Marx and Engels was based on historical necessity and the iron laws of historical materialism denoted the maturation process of societies towards communism. Socialism was history (Marx and Engels, 1970, pp. 36, 43, 45; Tschernilowski, 1980, p. 32). On the other hand, adhering to such an axiom opened the door for inconvenient questions concerning the existence of a bourgeois legacy within the legal orders of socialist societies. Had not Marx, Engels, and Lenin built their reasoning on previous philosophical and legal traditions? Should socialism also reject the concepts of Roman law, the ideals of natural law scholars, and the preceding bourgeois contribution in the fields of, e.g., contract and trade law?

However, attempts to historically contextualise the effectual legality of socialist societies did inevitably bring about larger dilemmas concerning the relation between an individual and the state, the nature and extent of universally valid and equal normative order, and the legitimation of the division of power (Joseph, 1995 , p. 583). The critical dialectical materialist view on the past was not be extended all the way to contemporary state socialism:

The basis for this development of law must be generally understood from the interests of the full application of [contemporary] norms. Hence, it does not mean that the exploration of the political and legal history of past epochs directly benefits the interpretation and application of Soviet law. That is impossible, and such a purpose cannot be seriously debated. $(\text { Tschernilowski, 1980, p. } 33)^{8}$

That said, due to its historical self-justification and constant competition with the West, the communist parties needed legal historical research and 'critical' legal historical analysis. The countries of the socialist bloc had to prove that their system was able to produce a considerable scientific output and display an academic sphere that was capable of competing with their Western counterparts (Mälksoo, 2018). 
With the model of the space of socialist interpretations of legal history, I have attempted to illuminate certain traits of continuity with regard to the 'bourgeois' or national tradition within the socialist legal historiography, and concurrently unfold the paradox that the communist parties both needed historical research to back their legitimacy and yet had to uproot vehemently some particular historical views. This was not a matter that concerned direct criticism of the party-such a thing did not belong to state socialism. Instead, a historical study of law that left the interconnections between law in the past and the contemporary socialist legality undone-even if the researcher represented the idea of the law as a learned tradition'-was from the party perspective harmless and, from time to time, useful as a façade (see, e.g., Sellnow, 1963, p. 16).

The communist parties to a degree encouraged theoretical explorations in legal science-advancement from 'revolutionary legality' was necessary in order to bring forth more sophisticated models. This offered some leeway for scholars to offer applicable historical knowledge without reducing law to a mere 'practice of political will.' Some employed 'the past' in their indirect criticism of the prevailing dogma and, by historically contextualising the discourse of MarxistLeninism itself, distinguished between proper socialism and dogmatism (Sellnow, 1968, p. 40; Mamut, 1979; Klenner, 1985). The communist parties were determined in controlling their sole authority to reinterpret the dogma of Marxist-Leninism and attacked dissenting scholarly views as well as regularly narrowed the space for accepted legal science. Nevertheless, their status as oracles deteriorated over time. Thus, the last decades of the socialist bloc were characterised by an increased scholarly interest in Marx's thoughts outside the official canon (Varga, 2016).

\section{Socialism and legal history}

In concrete terms, this book traces the essence of socialist legal historiography on three levels - the legal culture, the academic structures and legal principles, and the biographical sides of socialist legal historiography. The first part of the book, Framing the socialist legal historiography, traces the tensions between the European legal tradition and socialist legal orders, and the ways in which these frictions were overcome or, alternatively, emphasised. The tensions became evident especially in relation to the preceding canon of legal historical works and to 'Western' legal historiography.

Some of the individual chapters in the first part of the book investigate the relation between legal historiography and socialist society in the context of legal academia concentrating on the demands that communist society placed on legal historians and the scholars' response to these challenges as a community in the context of e.g. teaching and research questions. Some chapters in the first part also analyse shifting meanings and the use of the fundamental building blocks of European legal science, such as open concepts or traditional legal virtues, in socialist legal historiography. An example of this kind of use of the legal tradition is the drafting of Hungarian Civil Code of 1959. András Földi illustrates the way 
in which fundamental concepts of bona fides and boni mores maintained their connection to their original historical framing in the text of the new code and, despite pressure from the political sphere and hard core Marxist-Leninists, remained as gateways for legal interpretation in reference to the jurisprudential tradition rather than vehicles of socialist state planning.

In his article, Martin Otto gives an overview of the development of legal historiography in the GDR between the pressure of Sovietisation and the attempt of legal scholars to retain their identity as members of a distinguished discipline within legal studies. The article follows the process of the reestablishment of the law faculties in East Germany, their afterlife in a society that guarded knowledge production via structural rearrangements in higher education, and also scrutinises the dominant research themes in the GDR as a result of ideological restriction and lopsided, yet existing, international contacts.

One might assume that Soviet legal historiography and its view of the European past provided a model example in implementing the idea of 'revolutionary legality.' Certainly, the discipline experienced the political and ideological steering of state socialism first-hand, but the same paradox of the indispensability of acknowledging the historical roots in socialist legal science remained. In their chapter, Anton Rudokvas and Ville Erkkilä present the long line of Roman law studies in the Soviet Union and both highlight the effect that politically originated shifts in the research stance imposed on the understanding of Roman law and show that the field remained a background for further historical and legal studies. Marju Luts-Sootak focuses on the Baltic experience within legal historical teaching in the Soviet Union. Although the state curriculum was designed to give students an orthodox illustration of the relation between law and material historical continuity from the viewpoint of the emerging socialist thought, teachers were able to deploy a vast historical time span and include national elements in their de facto teaching. The strict coercion of the state could be evaded in a subtle use of emphasis and hyperbole.

Like many other concepts dealing with Russia and legal science, the 'communist legal tradition' is a simplification of a very rich and diverse tradition whose geographical context and borders with respect to other legal traditions are hard to define. Adolfo Giuliani addresses in his chapter the struggle to give a comprehensive definition for the legal historical development taking place both in the 'East' and the 'West.' Although legal historians in the West have constant problems in placing 'the East' in their narratives of European law, the 'communist legal tradition' has prevailed as a convenient other for the 'European legal tradition.' This from its start has enabled the construction of the coherent entity of the 'Western legal thought' that has accommodated legal and political scientific works on the essence and origins of human rights.

The second part of the book, Legal historians of socialist regimes, concentrates on some significant individual legal historians in East Central Europe. Their biographies and professional choices within drastically altering post-Second World War societies witness the deep intertwinement of personal values and scholarly work in 20th century European legal science. In what ways did scholars 
'start from scratch' after 1945, distinct from the 'bourgeois worldview' and previous historical narratives, and what stayed over from the inter-war period?

Of the countries in the socialist bloc, the GDR stands out as an example of the wide influence of the state in jurisprudence. Continuity with the national past was difficult because German scholarship in the 1930s and 1940s was used as an absolute antithesis to proper Marxist legal historiography. Some continuity, nevertheless, existed, and a few scholars who had started their careers in the preSecond World War period remained active in the academia of the GDR. Adrian Schmidt-Recla and Zara Luisa Gries examine the works of legal historian Gerhard Buchda and the continuities and discontinuities within them. Further emphasis is paid to the possible impact that Buchda's scholarly identity had on the thoughts of his students and on the methodology of the theses he supervised.

In some regions in East Central Europe, the drastic changes in the political climate of the early 20th century, from hegemonic nationalism to authoritarian and finally to state socialist, were more temporally concentrated, clear-cut, and thorough than in others. In the Baltic countries, scholars witnessed not only the devastating occupation of their home countries by Nazi troops but also their ruthless assimilation into the Soviet Union and the totalitarian rule of the public sphere associated with such political ruptures. Sanita Osipova examines the career of the Latvian legal historian Valdemārs Kalniņš and shows that despite Kalniņš carefully excluding any elements from his texts that might have been interpreted as a nod towards the recent national past, he nevertheless succeeded in preserving the idea of Latvian national legal entity in his works. Marta Bucholc portrays a parallel contradiction between the official ideology and methodology and the scholar's identity in her article on Polish historian Juliusz Bardach. Bardach is a tragic example of how the Second World War not only changed structures and ideologies but also affected scholars on a personal level. Yet despite, or possibly because of, his personal experiences during and right after the war, Bardach was able to forge a remarkable scientific career and became an established figure in Polish academia.

With the collapse of the socialist bloc, dialectical materialism or the Marxist stance have become more or less marginalized in the field of legal historical study. For understandable reasons, these theories are still heavily associated with state socialism, although they were not responsible for the legal nihilism that state socialism in itself advocated. The works of Elemér Pólay are examples of the fact that it was indeed possible to produce self-standing research on the history of law applying Marxist methodology and in societies that devalued legal science. In her article on Pólay, Éva Jakab describes Pólay's academic oeuvre but also focuses on the difficult moral and ethical choices he faced while pursuing a career as a legal scholar and later when he became a renowned historian of Roman law.

The socialist regimes of East Central Europe announced their systems as ultimate answers to the perennial questions of democracy, the rule of law, and social justice and excluded other alternative explanations as 'imperialistic.' In practice, however, their political and legal orders embedded bureaucratic illegality, in which the frames of legal institutes produced coercion, intolerance, and 
oppression. This volume, however, does not concentrate on that framework, but on the self-justification of the legal orders of state socialism, and on the dynamics within this legality, to which the ruling elite portrayed themselves as bound. Concentrating on the mere framework would exclude the phenomenon of socialist legal historiography from the wider context of European history, leaving it nothing more than a temporary abnormality, without roots and further consequences. The socialist interpretations of legal history compose a nuanced and diverse discourse at the core of the socialist project of East Central Europe, which tells a lot about the interaction between law and society. Analysing that level is the aim of our book.

\section{Notes}

1 'It is the main task of the science of state and law in the German Democratic Republic to educate men [...] to think in terms of dialectical materialism in dealing with questions of state and law, and to propagate insight into the requirements for development of our state and law during the construction of socialism.' Editorial in the leading East German legal journal Staat und Recht in 1958, quoted in Markovits, 1968, p. 14.

2 See Földi in this volume.

3 See Rudokvas and Erkkilä in this volume.

4 The figure is an adaptation of Juhana Aunesluoma's scheme, which he presented in his talk 'Narratiivit vastakkain. Kylmän sodan päättymiseen liittyvät historiakiistat', in Historiantutkimuksen päivät-conference (October 25, 2019) at the University of Oulu, Finland.

5 This was the change that Stalin introduced into the original dogma of MarxistLeninism (Stalin, 1951).

6 This was, of course, in line with the norm of the socialist states to evaluate not only the acts but also the intentions of its citizens and, if needed, to punish any dissident spirit (Stolleis, 2009).

7 'Während der bürgerliche Historiker seine Parteinahme zu verschleiern sucht, stellt sich der marxistische Historiker offen auf die Seite jener Klasse, deren Vertreter er selbst ist, vertritt er offen die Positionen der Arbeiterklasse, als einzig fortschrittlicher Gesellschaftklasse.'

8 'Die Gründe für diese Entwicklung des Rechts müssen im Interesse einer umfassenden Anwendung der Normen allgemeinverständlich sein. Daraus folgt nicht, dass dei Erforschung der Staats- und Rechtsgeschichte vergangener Epochen unmittelbar der Auslegung und Anwendung des sowjetischen Rechts zugute kommt. Das ist unmöglich, und ein solches Ziel kann nicht ernsthaft debattiert warden.'

\section{References}

Bena, J. (1999) 'Law Education in Czechoslovakia in the Years 1945-1989 with a special focus on the Comenius University Bratislava', in Bender, G. and Falk, U. (eds) Recht im Sozialismus. Analysen zur Normdurchsetzung in osteuropäischen Nachkriegsgesellschaften (1944/45-1989). Band 2 Justizpolitik, Frankfurt am Main: Vittorio Klostermann, 375-412.

Bender, G., and Falk, U. (1999) 'Einleitung', in Bender, G. and Falk, U. (eds) Recht im Sozialismus. Analysen zur Normdurchsetzung in osteuropäischen Nachkriegsgesellschaften 
(1944/45-1989). Band I Enteignung, Frankfurt am Main: Vittorio Klostermann, VII-XVI.

Boros, L., Gyulavári, Á., and Fleck, Z. (1999) 'Die Beteiligung von Laien an der Rechtspflege im sozialistischen Ungarn', in Bender, G. and Falk, U. (eds) Recht im Sozialismus. Analysen zur Normdurchsetzung in osteuropäischen Nachkriegsgesellschaften (1944/45-1989). Band 2 Justizpolitik, Frankfurt am Main: Vittorio Klostermann, 147-200.

Boros, L., Gyulavári, Á., and Fleck, Z. (1999) 'Juristenausbildung und Rechtserziehung in Ungarn von 1945 bis 1990', in Bender G. and Falk U. (eds) Recht im Sozialismus. Analysen zur Normdurchsetzung in osteuropäischen Nachkriegsgesellschaften (1944/45-1989). Band 2 Justizpolitik, Frankfurt am Main: Vittorio Klostermann, 337-374.

Bröstl, A. (2016) '20th Century Legal Philosophy in Czechoslovakia, the Czech Republic, and the Slovak Republic', in Pattaro, E. and Corrado, R. (eds) A Treatise of Legal Philosophy and General Jurisprudence: Volume 12, Legal Philosophy in the Twentieth Century: The Civil Law World, Dordrecht: Springer, 613-634. DOI: 10. 1007/978-94-007-1479-3_18.

Caldwell, P. C. (2003) Dictatorship, State Planning, and Social Theory in the German Democratic Republic, New York: Cambridge University Press.

Connelly, J. (2000) Captive University. The Sovietization of East German, Czech, and Polish Higher Education, 1945-1956, Chapel Hill and London: The University of North Carolina Press.

Cotterrell, R. (2015) 'Leon Petrażycki and contemporary socio-legal studies', International Journal of Law in Context, 11:1, 1-16. DOI: 10.1017/ s1744552314000330.

Csizmadia, A. (1968) 'Über die Beziehung der Rechtsgeschichtswisssenschaft zur Geschichtswissenschaft, den Fachrechtszweigen und zur Praxis', in Marxistische Beiträge zur Rechtsgeschichte, Berlin: Wissenschaftliche Schriftenreihe der Humboldt-Universität zu Berlin, 102-115.

Danyel, J., and Behrends, J. C. (2019)Grenzgänger und Brückenbauer. Zeitgeschichte durch den Eisernen Vorhang, Göttingen: Wallstein Verlag.

Eckert, J. (ed) (1993) Die Babelsberger Konferenz vom 2./3. April 1958. Rechtshistorisches Kolloquium 13.-16. Februar 1992 Christian-Albrechts-Universität zu Kiel, Baden-Baden: Nomos Verlag.

Erkkilä, V. (2019) The Conceptual Change of Conscience. Franz Wieacker and German Legal Historiography 1933-1968, Tübingen: Mohr Siebeck. DOI: 10. 1628/978-3-16-156692-9.

Fijalkowski, A. (2016) From Old Times to New Europe. The Polish Struggle for Democracy and Constitutionalism, London and New York: Routledge. DOI: 10. $4324 / 9781315583464$.

Fitzpatrick, S. (1979) Education and Social Mobility in the Soviet Union, 1921-1934, Cambridge: Cambridge University Press.

Fraser, D. (2019) 'Criminal law in Auschwitz: Positivism, Natural law and the Career of SS Lawyer Konrad Morgen', in Skinner S. (ed) Ideology and Criminal Law Fascist, National Socialist and Authoritarian Regimes, London: Bloomsbury, 33-58. DOI: 10.5040/9781509910847.ch-002.

Gizbert-Studnicki, T., Pleszka, K., and Wolenski, J. (2016) '20th-Century Legal Theory and Philosophy in Poland', in Pattaro, E. and Corrado, R. (eds) A Treatise 
of Legal Philosophy and General Jurisprudence: Volume 12, Legal Philosophy in the Twentieth Century: The Civil Law World, Dordrecht: Springer, 547-586. DOI: 10. 1007/978-94-007-1479-3.

Haferkamp H. P., and Wudtke T. (1997) 'Richterausbildung in der DDR', in forum historiae iuris, https://forhistiur.de/1997-10-haferkamp-wudtke/ (accessed 15.3.2020).

Heuer, U.-J. (1995) 'Nachwort', in Heuer, U. J. (ed) Die Rechtsordnung der DDR. Anspruch und Wirklichkeit, Baden-Baden: Nomos Verlagsgesellschaft, 611-622.

Joseph, D. (1995) 'Rechtswissenschaft und SED', in Heuer, U. J. (ed) Die Rechtsordnung der DDR. Anspruch und Wirklichkeit, Baden-Baden: Nomos Verlagsgesellschaft, 549-610.

Kaluza, A., (1999) 'Politischer Gegner im Blickfeld der prärogativen Politik des polnischen Parteistaates 1944-1956', in Bender, G. and Falk, U. (eds) Recht im Sozialismus. Analysen zur Normdurchsetzung in osteuropäischen Nachkriegsgesellschaften (1944/45-1989). Band 2 Justizpolitik, Frankfurt am Main: Vittorio Klostermann, $1-28$.

Kirby, D. (1994) 'Incorporation: the Molotov-Ribbentrop Pact', in Smith, G. (ed) The Baltic States. The National Self-Determination of Estonia, Latvia and Lithuania, London: Macmillan, 69-85.

Klenner, H. (1957) 'Zur ideologischen Natur des Rechts', in Staat und Recht im Lichte Des Grossen Oktober: Festschrift zum 40. Jahrestage der Grossen Sozialistischen Revolution, Berlin: VEB Deutschen Zentralverlag, 82-101.

Klenner, H. (1985) 'Gesellschaftsvertragstheorien vom 17. bis zum 20. Jahrhundert', in Klenner, H., and Müller, R. (ed) Gesellschaftsvertragstheorien von der Antike bis zur Gegenwart, Berlin: Akademie-Verlag, 31-75.

Kolár, P. (2016) Der Poststalinismus. Ideologie und Utopie einer Epoche, Köln, Weimar and Wien: Böhlau Verlag. DOI: 10.7788/9783412506490.

Kopeček, M. (2012) 'Human Rights Facing a National Past. Dissident "Civic Patriotism" and the Return of History in East Central Europe, 1968-1989', Geschichte und Gesellschaft, 38:4, 573-602. DOI: 10.13109/gege.2012.38.4.573.

Koselleck, R. (1987) 'Geschichte, Recht und Gerechtigkeit', in Simon, D. (ed) Akten des 26. Deutschen Rechtshistorikertages Frankfurt am Main, 22. bis 26. September 1986, Frankfurt am Main: Vittorio Klosterman, 129-152.

Kramer, M. (2017) 'The Changing Pattern of Soviet-East European Relations 1953-1968', in Naimark, N., Pons, S., and Quinn-Judge, S., (eds) The Cambridge History of Communism, Cambridge: Cambridge University Press, 139-169. DOI: 10.1017/9781316459850.007.

Lenin, V. I. (1977) Valitut teokset. Vol 9 (Collected works. Vol 9), Moscow: Kustannusliike Edistys.

Liebrecht, J. (2018) Die junge Rechtsgeschichte. Kategorienwandel in der rechtshistorischen Germanistik der Zwischenkriegszeit, Tübingen: Mohr Siebeck.

Luhmann, N. (1984) Soziale Systeme. Grundriß einer allgemeinen Theorie, Frankfurt am Main: Suhrkamp.

Lässig, S. (2007) 'Between Two Scholarly Cultures: Reflections on the Reorganization of the East German Historical Profession after 1990', Central European History, 40:3, 499-522. DOI: 10.1017/s0008938907000817.

Mamut, L. (1979) Fragen der Staatstheorie im ideologischen Widerstreit, Moscow: Progress Verlag. 
Markovits, I. S. (1968) 'Civil Law in East Germany-Its Development and Relation to Soviet Legal History and Ideology', Yale Law Journal, 78:1, 1-51.

Markovits, I. S. (2018) 'Drei Geschichten einer Fakultät. Ostdeutsche Juraprofessoren im Sozialismus', in Haferkamp H. P., Thiessen, J., and Waldhoff, C. (eds) Deutsche Diktatorische Rechtsgeschichten? Perspektiven auf die Rechtsgeschichte der DDR. Gedächtnissymposium für Rainer Schröder (1947-2016), Tübingen: Mohr Siebeck. 33-50. DOI: 10.1628/978-3-16-156696-7.

Marx, K., and Engels, F. (1970) Kommunistisen puolueen manifesti, Helsinki: Kansankulttuuri Oy.

Mälksoo, L. (2018) 'The Controversy over Human Rights, UN Covenants, and the dissolution of the Soviet Union', Japanese Yearbook of International Law, 61:1, 260-283.

Naimark, N. (2017) 'The Sovietization of East Central Europe 1945-1989', in Naimark, N., Pons, S., and Quinn-Judge S. (eds) The Cambridge History of Communism, Cambridge: Cambridge University Press, 63-86. DOI: 10.1017/ 9781316459850.004.

Ostermann, C. F. (2001) Uprising in East Germany, 1953: The Cold War, the German Question, and the First Major Upheaval behind the Iron Curtain, Budapest: CEU Press.

Otto, M. (2008) Von der Eigenkirche zum Volkseigenen Betrieb: Erwin Jacobi (1884-1965), Tübingen: Mohr Siebeck.

Poláčková, Z., and van Duin, P. C. (2019) 'Gustáv Husák and the Foundations of 'Normalization': Slovak, Czechoslovak and Federative Perspectives 1968-197', Slavonica, 24:1-2, 36-51. DOI: 10.1080/13617427.2019.1623460.

Pomeranz, W. E. (2019) Law and the Russian State: Russia's Legal Evolution from Peter the Great to Vladimir Putin, London: Bloomsbury Academic. DOI: 10. $5040 / 9781474224253$.

Raff, M., and Taitslin, A. (2014) 'Property Rights under Socialist Civil Law: Looking Back to the Twentieth Century.' in Simons, W. B. (ed) East European Faces of Law and Society: Values and Practices, Leiden and Boston: Brill | Nijhoff, 251-306. DOI: 10.1163/9789004285224_009.

Reimann, M., Zimmermann, R., and Glenn, H. (2019) 'Comparative Legal Families and Comparative Legal Traditions,' in The Oxford Handbook of Comparative Law, London and New York: Oxford University Press, 423-440. DOI: 10.1093/ oxfordhb/9780198810230.013.13.

Richardson-Little, N., Dietz, H., and Mark, J. (2019) 'New Perspectives on Socialism and Human Rights in East Central Europe since 1945. Introduction to the Thematic Issue', East Central Europe, 46:2-3, 169-187. DOI: 10.1163/ 18763308-04602004.

Schmidt-Hartmann, E. (1988) 'Forty Years of Historiography under Socialism in Czechoslovakia. Continuity and Change in Patterns of Thought', Bohemia. Zeitschrift für Geschichte und Kultur der böhmischen Länder, 29:2, 300-324.

Schröder, H. (1980) 'Vorwort des Herausgebers' in Tschernilowski, S. M., Allgemeine Staats- und Rechtsgeschichte. Von der Entstehung des Staates bis zum Kapitalismus. Lebrbuch, Berlin: Staatsverlag der Deutschen Demokratischen Republik, 25-34.

Schröder, J. (2016) Rechtswissenschaft in Diktaturen. Die Juristische Methodenlehre im NS-Staat und in der DDR, München: C. H. Beck. 


\section{Ville Erkkilä}

Schöneburg, K. H. (1987) 'Aneignung der Wissenschaftsgeschichte als konstitutives Elemente der Wissenschaftlichkeit. Geschichte und Gegenwart der Staats- und Rechtstheorie', in Köhn, J. and Rode, B. (eds) Eigentum. Beiträge zu seiner Entwicklung in politischen Gesellschaften. Werner Sellnow zum 70 Geburtstag, Weimar: Hermann Böhlaus Nachfolger, 306-321.

Sellnow, W. (1963) Gesellschaft - Staat - Recht. Zur Kritik der bürgerlichen Ideologien über die Entstehungen von Gesellschaft, Staat und Recht, Berlin: Rütten \& Loening.

Sellnow, W. (1968) 'Zum Problem der Rechtsgeschichte im System von Marx und Engels' in Marxistische Beiträge zur Rechtsgeschichte, Berlin: Wissenschaftliche Schriftenreihe der Humboldt-Universität zu Berlin, 40-71.

Skinner, S. (2019) 'Introduction: Glancing in the Mirror at Ideology and Criminal Law Under Fascist, National Socialist and Authoritarian Regimes', in Skinner, S. (ed) Ideology and Criminal Law Fascist, National Socialist and Authoritarian Regimes, London: Bloomsbury, 1-6. DOI: 10.5040/9781509910847.0006.

Stalin, J. (1951) Marxism and Linguistics, New York: International Publishers.

Stolleis, M. (2009) Sozialistische Gesetzlichkeit. Staats- und Verwaltungsrechtswissenschaft in der DDR, München: Verlag C. H. Beck.

Tschernilowski, S. M. (1980) Allgemeine Staats- und Rechtsgeschichte. Von der Entstehung des Staates bis zum Kapitalismus. Lebrbuch, Berlin: Staatsverlag der Deutschen Demokratischen Republik.

Varga, C. (2016) '20th-Century Legal Philosophy in Hungary', in Pattaro, E. and Corrado, R. (eds) A Treatise of Legal Philosophy and General Jurisprudence: Volume 12, Legal Philosophy in the Twentieth Century: The Civil Law World, Dordrecht: Springer, 635-651. DOI: 10.1007/978-94-007-1479-3_19.

Wieacker, F. (1967) Privatrechtsgeschichte der Neuzeit. Unter besonderer Berücksichtigung der deutschen Entwicklung. 2., neubearbeitete Auflage, Göttingen: Vandenhoeck \& Ruprecht.

Zagladin, V. (1983) Sosialistisen yhteiskunnan historiallinen tehtävä (Socialism: its role in history), Moscow: Kustannusliike Progress. 